\title{
Introduction
}

\section{Histories of knowledge in postwar Scandinavia}

\author{
Johan Östling, Niklas Olsen, and David Larsson Heidenblad
}

All societies are knowledge societies. It is hard to imagine a culture or country lacking basic orders, institutions, and actors of knowledge. However, the very term "knowledge society" is of a recent date and belongs to a special phase in postwar history. In the late 1960s and early 1970s, researchers and intellectuals, mainly American social scientists, started claiming that the West had entered a new stage beyond industrial society. Robert E. Lane, Peter Drucker, and Daniel Bell at this time emphasised the exponential growth of knowledge and its ever-increasing importance in modern society. They maintained that what distinguished the post-industrial society was the change in the character of knowledge itself. ${ }^{1}$ In the years to come, sociologists and economists started to talk more and more about the "knowledge society". Gradually, this concept was turned into a self-understanding that was taken over by politicians, policymakers, and others wanting to find a new formula for the contemporary condition. ${ }^{2}$

This is a book about the place and significance of knowledge in this society that was beginning to refer to itself as a knowledge society. To be more precise, it studies how knowledge was made, negotiated, circulated, contested, and used in different public arenas, shaping politics, economics, social, and cultural life. At the centre, we find Scandinavia during the 1960s and 1970s, three countries Denmark, Norway, and Sweden - which were examples of Western European welfare states but with their own distinct features. ${ }^{3}$

For historians seeking to transcend the confines of national boundaries, postwar Scandinavia offers many advantages. The three societies were in many respects similar - culturally, politically, linguistically, etc. - yet upon closer inspection also notably different from each other. If we, for example, focus on energy history, trade, and industry, or the relative strength of social democracy, postwar Scandinavia is a mosaic rather than a monolithic entity. Moreover, there were many linkages, interrelations, networks, and co-operative ventures that require a transnational gaze to study. Finally, from a scholarly point of view, Scandinavian historians are connected through institutions, meetings, exchanges, and journals. This social and intellectual infrastructure facilitates comparative and transnational endeavours. ${ }^{4}$

When studying postwar Scandinavia in the present volume, our shared point of departure is the history of knowledge. We take advantage of contemporary 
historiographical discussions on the circulation, arenas, forms, applications, and actors of knowledge in this fresh field. In addition, the book empirically substantiates many of the general claims made in the field of the history of knowledge in the 2010s. Bringing together thirteen Swedish, Danish, and Norwegian researchers from different historical disciplines (history, economic history, history of ideas, history of the book), we seek to shed new light on concrete postwar Scandinavian settings and contribute to the development of the history of knowledge at large.

\section{History of knowledge}

The history of knowledge has emerged as a scholarly enterprise over the course of the last fifteen years. The earliest elaborate discussions took place in Germanspeaking Europe under the name of Wissensgeschichte. In the English-speaking world, history of knowledge was initially met with modest attention but has established itself as a dynamic and expanding field since the mid-2010s. In the years running up to 2020, conferences were organised, journals were founded, and book series were launched. ${ }^{5}$

When surveying contemporary scholarship, it is obvious that there are several parallel understandings of history of knowledge and what it comprises. ${ }^{6} \mathrm{How}-$ ever, by putting knowledge at the centre of the historical endeavour, history of knowledge has evidently managed to provide a productive platform where approaches from a large number of different disciplines may be brought together and cross-fertilise each other. At the same time, history of knowledge has a generative capacity to create new questions, perspectives, frameworks, methods, themes, and concepts that are not part of existing discourses or practices. By doing so, original contributions can be made to general historiography. ${ }^{7}$

One dominant understanding of the field stresses knowledge as a fundamental category in society. Philipp Sarasin, for instance, has proposed that history of knowledge should be about "the societal production and circulation of knowledge". In his mind, knowledge circulates between people, groups, and institutions. This does not mean that knowledge spreads freely and is evenly distributed but rather that it can be communicated in other fields of knowledge where it will interact with different societal contexts. ${ }^{8}$ Similarly, Simone Lässig looks upon the field as a form of social and cultural history examining knowledge as a phenomenon that touches almost every sphere in human life. She maintains that "The history of knowledge does not emphasise knowledge instead of society but rather seeks to analyse and comprehend knowledge in society and knowledge in culture." $\mathrm{We}$ (Östling and Larsson Heidenblad) have in various texts emphasised that when pursuing the history of knowledge, there should be a focus on the role of knowledge in society. ${ }^{10}$

One way of studying knowledge in society is to employ the concept of circulation. Within history of knowledge, this is an analytical framework that has attracted a great deal of attention in recent years. United in a professed intention to renounce simplistic diffusionist models and theories of linear dispersion, 
scholars have in a number of studies used circulation to analyse how knowledge moves and how it is continuously moulded in the process. ${ }^{11}$ Despite its virtues, circulation in many ways remains analytically elastic and ambiguous. Kapil Raj has characterised it as a "recurrent, though non-theorized concept", and James A. Secord has lamented that it runs the risk of becoming a "meaningless buzzword". ${ }^{12}$ As valuable as it is, the very concept of circulation is thus in need of clarification and elaboration.

The concept of circulation is also central to this book. However, it is applied alongside a number of additional perspectives on the history of knowledge, including how different forms of knowledge have been constructed, discussed, challenged, transformed, and mobilised in order to shape and influence various social, political, or cultural contexts. In this respect, our approach differs slightly from various forms of intellectual history, which tend to focus on tracking and tracing the origins of ideas of significant thinkers and how these thinkers have drawn on, reworked, or distanced themselves from various discursive fields, etc. ${ }^{13}$

Against this background, in this book we demonstrate how these perspectives may enrich our understanding of knowledge in society. First, the contributions in the book thus address broader, societal forms of knowledge. At the heart of these studies are major political, cultural, or economic phenomena related to knowledge in postwar society - not knowledge in everyday life or forms of knowledge that only affected a small intellectual elite. Second, we concentrate on a chronologically defined phase of modern history, the 1960s and 1970s, although some contributions begin earlier and others end later. This means that several of the contributions in one way or another relate to key concepts during this era - modernity, democracy, progress, welfare state, the public sphere, etc. Third, we concentrate on Denmark, Norway, and Sweden. By putting three Scandinavian countries at the centre, we are able to highlight specific geographical, cultural, and historical conditions for knowledge circulation.

\section{Postwar Scandinavia}

"For a small, sparsely populated region on the margins of Europe, Scandinavia seems to have generated an interest out of all proportion to its size", Mary Hilson states in the introduction to her 2008 book The Nordic Model. This might be true; however, at the same time, Hilson's work serves as a rare example of a substantial historiographical account encompassing all Nordic countries. As Harald Gustafsson points out in Nordens historia (2017), the most ambitious, up-to-date overview that exists, pan-Nordic historical syntheses that are also based on scholarship are few and far between. As a general rule, most studies have a national framework. ${ }^{14}$

Turning to histories of postwar Scandinavia, the lion's share of the research literature has been shaped by a limited number of overarching narratives. The rise, development, and crisis of "the welfare state" and "the Scandinavian/Nordic model" have arguably been the most dominant patterns of interpretation, both 
in more general treatments and more specific studies. ${ }^{15}$ The previously mentioned book by Hilson is an obvious example, but the theme is prevalent in a multitude of studies, such as the edited volume The Nordic Model of Welfare (2006) and Francis Sejersted's monograph The Age of Social Democracy (2011). ${ }^{16}$

Another theme recurring in scholarship on postwar Scandinavia is the foreign and security policy of the region during the Cold War. With Denmark and Norway as founding members of the North Atlantic Treaty Organisation (NATO) and Sweden as a non-aligned country, the shifting relationships to both the Soviet Union and the Western powers have attracted a fair amount of attention. This field has traditionally been dominated by political and diplomatic approaches but has in recent years been enriched by cultural and media history, including titles such as The Nordic Media and the Cold War and Nordic Cold War Cultures. ${ }^{17}$ Related to these books are studies on how the memories of the Second World War have shaped national identities and security policy doctrines in the Scandinavian countries since $1945 .{ }^{18}$

Apart from these two key themes, a fair number of volumes were published in the 2010s addressing particular dimensions of postwar Scandinavia or the Nordic countries, even though some of these had a contemporary rather than a historical perspective. This included books on Nordic cooperation, on gender equality and gender research, and on various aspects of the political culture, including rhetorics of democracy and human rights norms. ${ }^{19}$

However, none of these studies analyse postwar Scandinavia as knowledge societies. The closest we get is In Experts We Trust (2010), a valuable collection on knowledge, politics, and bureaucracy in Nordic welfare states. The majority of the contributions uncover the interplay between science, experts, and politics in policy areas (psychiatry, public health, social insurance, etc.) prior to the 1960 s. $^{20}$

In this volume, by contrast, we concentrate on the role of knowledge in Scandinavian societies of the 1960s and 1970s and analyse how various forms of knowledge circulated and were put into practice. This shift in focus, from "welfare" to "knowledge", means that new contexts take centre stage. This introduction is not the right place to elaborate on every conceivable context of relevance for the individual chapters, but there are reasons to point to some major societal trends and structures that are of recurring importance during these postwar decades.

A distinctive feature for Scandinavia was the strong position of social democracy. In all three countries, the social democratic parties had come to power during the interwar period and exerted great influence for decades after 1945. By virtue of their position, not only did they fundamentally shape the emerging welfare states and many of their institutions and organisations, they also put their distinct mark on the cultural life, the educational system, and applied social research. Francis Sejersted has characterised the period between 1940 and 1970 as "the Golden Age of the Social Democracy". At the same time, there were differences between the countries. In Sweden, social democracy uninterruptedly held government positions from the 1930s to 1976, during 
some periods with an absolute majority. The Danish Social Democrats led the government between 1953 and 1968 but would then lose some of its significance even if they returned to office. The great days of the Norwegian Labour Party ended in 1965, but here, too, Social Democrats were able to regain power in the 1970s. Thus, in all three countries, the social democratic hegemony was challenged during the period that is the centre of the discussion of this book. ${ }^{21}$

The left-wing radicalism of the late 1960s altered the conditions for politics, public debate, and knowledge circulation. As in the rest of Western Europe, "1968" in Scandinavia was characterised by criticising the establishment, a global engagement, and demands for social and democratic change. Thomas Ekman Jørgensen has argued that there were significant similarities between the Scandinavian left-wing movements, but he has also identified differences. Norway and Sweden "present a model with the predominance of Maoism and clashes between center and periphery, whereas the student movement and theoretical Marxism dominated the scene in Denmark." In a larger international perspective, however, the Scandinavian development was distinguished by its low level of social conflict and high level of social integration. "This remarkable ability to integrate and use the 1968 protests to reform and even stabilize Scandinavian society makes it stand out as a special case among the other European 1968s", Ekman Jørgensen concludes. ${ }^{22}$

However, the established order was not only challenged from the left. During the second half of the 1960s and to an even greater extent in the 1970s, new ideological dimensions opened up. The women's movement shaped public opinion and put gender equality on the political agenda. Decentralisation and the environment became important political issues. At the same time, the social and economic model of the postwar decades was attacked from the right. In the early 1970s, Mogens Glistrup in Denmark and Anders Lange in Norway founded populist parties calling for strong reductions in taxes and social welfare expenditure. ${ }^{23}$ Altogether, the 1970s signalled change in the Scandinavian political landscapes, as social democratic governments had difficulties responding to the contemporary economic crisis and the widespread criticism of their welfare state project. Not only did they lose power to parties pursuing more economically liberal visions, they also gradually moved away from their traditional political platform and came to share some of the ideological visions held by their opponents. This included the vision of making the public sector more effective by introducing market models, ideals of decentralisation, and free choice in the public provision of services and goods. ${ }^{24}$

All in all, these political and ideological circumstances affected the making, circulation, and negotiations of knowledge. Another key context was the radical change and expansion of the education system. In all three Scandinavian countries, an egalitarian system was introduced during this period where pupils went to the same schools regardless of their aspirations and backgrounds. More and more students also moved on to upper-secondary school, which simultaneously underwent a change from older, socially exclusive institutions to large schools for wider groups of young people. ${ }^{25}$ In addition, there is a strong 
tradition of popular and adult education in Scandinavia that was very much alive during the first postwar decades, although there were sometimes significant differences between the three countries in terms of pedagogical ideals and legacies. $^{26}$

In short, the level of education increased during the 1960s and 1970s, and the rise of the mass universities greatly contributed to this development. Even though there are differences between the Scandinavian countries, the similarities are more conspicuous. In the years after 1960, a coherent national research and higher education policy emerged. In keeping with the ideals of large-scale planning of the time, bureaucrats and politicians started to seriously look upon research and universities as central societal assets. What truly paved the way for a new kind of university, however, was the astonishing transformation of the student population. Not only the sheer number of students multiplied but the proportion of women also increased rapidly and the social base for student recruitment became more mixed. The driving force behind this huge expansion was aspirations for prosperity, technological advances, and a more equal society. ${ }^{27}$

At the beginning of the period, academic life in Scandinavia was dominated by a few well-established universities: Copenhagen and Aarhus in Denmark, Bergen, Oslo, and Trondheim in Norway, and Gothenburg, Lund, Stockholm, and Uppsala in Sweden. By the end of the 1970s, a number of new universities had been founded - Aalborg, Odense, Roskilde, Umeå, Linköping, and Tromsø - together with other institutions of higher education. The result was a more diversified intellectual landscape, where an older academic culture was challenged by new organisational forms and scientific ideals. ${ }^{28}$

These were some of the characteristics of Scandinavia in the 1960s and 1970s. Could these political structures, social arrangements, intellectual currents, and cultural orders be studied as knowledge societies? In this book, we seek to do so by focusing on the role of knowledge in the public sphere.

\section{Histories of knowledge in the postwar public sphere}

Like the political, social, and educational systems, the public sphere exhibited significant similarities between the Scandinavian countries. During the 1960s, the press had a strong position, and virtually every household subscribed to at least one daily newspaper in what was a fiercely competitive newspaper market. At the same time, the entire media landscape was gradually changing, not least due to the introduction of television from the mid-1950s. Left-wing radicalism in the late 1960s and early 1970s not only put new issues on the agenda but also paved the way for new media forms. An important component in the public circulation of knowledge at the time was intellectual journals, whether they had a political, cultural, or theoretical ambition. This general picture is true for Scandinavia as a whole, but there were also obviously national variations. For instance, Danish Weekendavisen, founded in 1971 as a highbrow weekly covering politics, culture, and science, soon became influential but had no equivalent in Norway or Sweden. ${ }^{29}$ 
This postwar public sphere serves as one of several important contexts in this volume. In order to explore the three Scandinavian countries as knowledge societies, we have also been inspired by recent insights from the history of the book. As an entry point in their analyses, many authors in this volume use a non-fiction book that circulated in the public sphere. After all, the postwar decades at the centre of our attention have been characterised by Michael Hagner as "the golden age of the scholarly book", a period when ambitious books deriving from the humanities and social sciences played a significant role in shaping public discourses and debates. ${ }^{30}$ At the same time, these books were part of the larger cultural infrastructure of the time: they were reviewed in newspapers and on the radio, and they were debated on television and in student communities. ${ }^{31}$

How, then, are we to study processes, situations, or contexts where knowledge gained societal significance in Scandinavia during this period? There are a number of possible frameworks. ${ }^{32}$ In this book, we introduce three methodological approaches utilised for writing our histories of knowledge in Scandinavia during the 1960s and 1970s: actors, arenas, and aspirations. As concepts, they are not equally applied by all authors or in all chapters; rather, they work as a shared analytical toolkit that helps us focus on certain objects of knowledge and discuss similarities and dissimilarities.

A broad range of historical actors are instrumental for producing, circulating, negotiating, contesting, and politicising knowledge. However, in historiography the position as "knowledge actor" is often reserved for those residing at the centre of learned spheres, typically scientists and scholars. Hence, in this book we have deliberately sought to widen the scope and type of actors we examine.

Among the knowledge actors under scrutiny in this volume, we find entrepreneurs, booksellers, journalists, populist politicians, and Christian commentators. Furthermore, when studying academic actors, we primarily analyse their role as public intellectuals, thereby shifting focus from the inner workings of science and scholarship to the public sphere. Taken together, this joint focus on knowledge actors opens up for elucidating comparisons and larger discussions on the prospects, and confines, of historical agency.

An arena of knowledge may in this context be understood as a place or a platform in its given framework offering the opportunity and setting the limits for certain forms of circulation of knowledge. It serves as a site for interactions between knowledge actors and their audiences. In order to be an arena promoting knowledge in society, it typically needs a measure of stability and persistence, although the actual content of knowledge existing in one and the same arena may vary over time. ${ }^{33}$ As in all forms of circulation processes, knowledge does not move freely in an arena. An arena of knowledge has its own medial and rhetorical norms and limitations that contribute to rewarding and supporting certain types of knowledge, while others are rejected or ignored. Its position as a societal arena of knowledge is dependent both on the general historical context and on how it is perceived in specific moments. In addition, an arena of knowledge can be seen as an element in a society's larger infrastructure for knowledge. ${ }^{34}$ 
In this volume, we highlight a number of different arenas of knowledge in postwar Scandinavia. A typical example is a non-fiction paperback series or an essay section in a newspaper devoted to scholarly communication. Another kind of arena includes pedagogical publications (such as teachers' manuals) and academic communities (such as research councils). Physical sites represent yet another form (e.g., socialist book cafes). Taken together, arenas were crucial for knowledge in the societies of the 1960s and 1970s.

Actors always produce, disseminate, and mobilise knowledge with the aspiration to achieve something. Boiled down, knowledge is directed towards either upholding or changing an existing state of affairs. For example, in the case of postwar Scandinavia, politicians, scholars, and intellectuals have constructed and propagated forms of knowledge with the intention of legitimising and challenging the social democratic welfare state. ${ }^{35}$ However, knowledge aspirations can be framed in many different (and more or less explicit) ways and have several different outcomes. Indeed, they often have consequences that their proponents neither desire nor control. Against this background, this volume seeks to grasp how, in a variety of arenas, actors in postwar Scandinavia have produced and circulated knowledge with the aspiration to achieve something as well as to look into the various outcomes of their aspirations.

In terms of the empirical studies, the book focuses on three larger fields of knowledge: (1) the environment and global crises; (2) economy, politics, and the welfare state; and (3) education, culture, and the humanities. These three fields were vital for the self-understanding of the Scandinavian societies of the 1960 s and 1970 s, but they had different status, temporalities, and public impact. Moreover, they are rarely studied together. By analysing them as part of the same context, we are able to chart larger historical patterns and write a more comprehensive history of knowledge of postwar Scandinavia.

\section{The environment and global crises}

In the aftermath of the Second World War, it became evident that human survival was at stake. The looming threat of thermonuclear war paved the way for a new sensibility in relation to global crises: overpopulation and dwindling natural resources in the 1940s and 1950s, environmental degradation and pollution in the 1960s, and - especially from the 1980s onwards - climate change. Central to these interlinked histories was the emerging idea of the environment, which developed in tandem with new international bodies of science and governance, as well as technological advancements originating from large-scale Cold War military research programmes. ${ }^{36}$

In Scandinavia, these global developments merged - and interacted - with different national trajectories. At this time, Sweden, unscathed by the war, was the richest and most centralised of the three societies. Ambitious research programmes were launched, not least on the possibility of acquiring nuclear weapons, and in the 1970 s, Sweden - as the only Scandinavian nation - erected nuclear power plants. In Denmark, such plans were met with fierce popular 
resistance, and the nation instead came to rely on imported energy, notably coal. In Norway, as in Sweden, hydropower was important and contested - but the discovery of North Sea oil in the late 1960s was even more critical. Hence, the emergence of modern environmentalism in Scandinavia - the so-called ecological turn - took on quite different forms, chronologies, and focal points in the three societies. ${ }^{37}$

The contributions in this part stretch from grappling with radioactive fallout and overpopulation in the 1950s, over the emergence of environmentalism in the 1960s, to the social and political movements of the late 1970s. This part demonstrates that the heightened awareness of global crises made a thorough mark on Scandinavian societies and highlights how knowledge was made, circulated, contested, and put into political use.

Casper Sylvest examines the debate over radioactive fallout from nuclear weapons testing that unfolded from the mid-1950s to the early 1960s. It was a complicated and wide-ranging dispute over knowledge, including questions concerning the properties of fallout, its long-term health effects, and whether civil defence was, in fact, even possible. In his chapter, Sylvest focuses on how this international debate was received, reflected upon, and replayed in Denmark. To a striking extent, the Danish scientific debate structurally mirrored American developments: it was dominated by two opposing scientific positions that drew much of their force from similarly opposing fractions abroad. Disagreements among scientists caused much bewilderment among civil defence officials. The question became steadily more contentious as calls for public information increased. The analysis highlights the limitations and political pressures on knowledge production in a small, dependent state during the height of the Cold War.

Sunniva Engh focuses on how global concerns for overpopulation, food scarcity, and impending resource shortages were discussed in the Norwegian press during the 1950s and 1960s. Her entry point is the Swedish-American scientist Georg Borgström, who published numerous books on the population-resource dilemma, arguing that a solution lay in Neo-Malthusian family planning efforts. From the late 1940s onwards, he appeared with increasing regularity in Norwegian media, and through a number of public appearances, lectures, and radio broadcasts, he actively disseminated his message. Engh demonstrates how Borgström, in the late 1960 s, became a public celebrity in Norway. Moreover, she highlights how the population-resource dilemma fuelled and shaped the emergence of modern environmentalism in Norway.

David Larsson Heidenblad studies the role of journalists in the emergence of modern environmentalism in 1960s Sweden. He argues that the recent digitalisation of newspapers provides historians with new opportunities to study this particular category of knowledge actors in depth. In order to discuss and demonstrate the practical implications of this argument, his chapter focuses on Barbro Soller and Tom Selander - two Swedish reporters who turned to environmental journalism in the 1960s. Larsson Heidenblad's study shows how, when, and why this happened, thus challenging chronologies put forth 
in previous research. He emphasises that fully text-searchable digital archives should be treated with great care. The chapter highlights methodological pitfalls and blind spots as well as arguing for the advantages of adopting a multiarchival approach.

Bo Fritzbøger's chapter highlights a momentous event in the history of Danish environmentalism: the publication of Revolt From the Center in 1978. This book addressed a broad range of topics: global inequality, physical limits to continued growth, environmental pollution, and the inhumanity of modern, urban life. It immediately aroused great interest and became the focal point of a sustained public debate. Fritzbøger traces not only the book's conceptual sources but also its social, intellectual, and political consequences. In particular, he examines what happens when ideas and knowledge are translated into a social movement. He concludes that the enticingly broad approach of the book, which sparked wide interest and engaged readers, was also the primary cause for the failure to launch a powerful and persistent movement with long-term political impact.

\section{Economy, politics, and the welfare state}

The political economies of the Scandinavian welfare states have constituted an important area of knowledge in the postwar period. To begin with, the distinctly Scandinavian welfare model, in which the state came to play a key role in the protection and promotion of the social and economic well-being of its citizens, required academic and political explication and legitimation. For this purpose, politicians, intellectuals, and scholars, often associated with the social democratic parties, made knowledge claims not only regarding the workings of governments and markets but also regarding a number of additional issues, such as gender roles, that supported their welfare state project. This knowledge production and circulation took place in many areas, including the public debate, political programmes, scholarly and political journals, academic books, and institutional reports and agendas. This was also the case when the traditional knowledge of the desired political economy of the welfare state was increasingly challenged, and alternative visions were introduced during the 1970s and 1980s.

The four contributions to this part of the book provide various perspectives on the construction, dissemination, and constructed nature of the knowledge created regarding the political economies of the Scandinavian welfare state.

Björn Lundberg focuses on the reception of American economist John Kenneth Galbraith's book The Affluent Society (1958). He explores the social criticism of growth as an example of transnational circulation of knowledge in Scandinavia in the early postwar era. The chapter does not discuss Galbraith's ideas per se; instead, it analyses how his ideas and arguments circulated, were picked up, and transformed in a Scandinavian setting by social democratic parties and politicians as well as by protagonists with other political affiliations. An analysis of newspaper journalism from Sweden, Denmark, and Norway 
discussing Galbraith's book and the concept of the affluent society is used for illustrating that the discourse on affluence and welfare shared common traits in these countries but were also characterised by differences explained with reference to factors such as the geopolitical currents of the Cold War.

Niklas Olsen documents how the 1970s saw the rise of a new kind of knowledge concerning the welfare state in Denmark. Voiced by politicians, social commentators, and scholars, this knowledge was critical by nature and depicted the welfare state as an enterprise run by a new ruling class - the public employees in control of the public sector - against the interests of the majority of the population. In other words, it introduced a new mode of welfare state criticism framed as criticism of the elite and challenging the fundamental values and the very legitimacy of the welfare state model that had been created in the postwar era. The chapter describes the advent of welfare state criticism as elite criticism in the Danish political debate, as it unfolded in debate books, journals, and through the invention of a new vocabulary to describe the state and its employees. It also traces some of the consequences of this criticism in a longterm perspective.

Orsi Husz explores a book project initiated in 1976 by the owner of a Swedish credit card company, Erik Elinder. Aiming to reshape hostile attitudes towards consumer credit among both politicians and the general public, Elinder commissioned two economic historians for a research-based but popular book about the history of consumer credit. By exploring a unique archival material, this chapter reveals how marketing strategies of de-stigmatisation were intertwined with knowledge circulation not of the book itself but through extensive networking in Sweden and abroad alongside the project. Moreover, the chapter uses exchanges between Elinder and the scholars hired to write the book for highlighting "the boundary work" that involved negotiating boundaries between university research and business operations and balancing between the symbolic and economic values of knowledge.

Eirinn Larsen revisits Scandinavian state feminism by exploring its various origins and places of knowledge as well as its support in social movements and state bureaucracy in the 1970s and 1980s. In so doing, it challenges, or expounds, the understanding first provided by Helga Hernes in 1987 that women's political activism "from below" in a compromise over state reform "from above" in the mid-1980s made Nordic societies increasingly woman-friendly. Empirically, it spans key Scandinavian institutions of knowledge production, including the Norwegian Research Council and its so-called Secretariat of Feminist Research established in 1977 and the Nordic Council of Ministers. As such, the chapter provides an example of how knowledge of the political economy of the welfare state developed.

\section{Education, culture, and the humanities}

During the early postwar period, the humanities were still part of an older culture of learning, with close links to well-established universities, educational 
institutions, book publishers, and churches. Influenced by American models, new pedagogical and scientific ideals were introduced from the late 1950s. Gradually, power relations within academia were altered: the social sciences, behavioural sciences, natural sciences, and engineering advanced their positions, while the humanities and theology lost in importance. In the increasingly rationalistic and secular climate of the 1960s, new ideas about man and society crystallised. ${ }^{38}$

These overall tendencies are reflected in the four contributions in the last part of the book. The gradual transformation of the education system and human sciences in Scandinavia during the 1960s and early 1970s paved the way for a different public sphere, including new publishing houses, such as Cavefors in Sweden and Pax in Norway. At the same time, it is obvious that old and new forms of knowledge could co-exist. Several of the chapters demonstrate the tensions arising when an established order was challenged by something new. ${ }^{39}$

Anton Jansson's point of departure is the postwar secularisation theory. Positing a necessary and universal link between modernisation and the disappearance of religion, it enjoyed a strong status as almost taken-for-granted knowledge in the 1960s. However, there were different ways of understanding secularisation. This chapter studies the Swedish translation of American theologian Harvey Cox's The Secular City, which was published in two editions (1966 and 1967) by the publishing house of the Church of Sweden. Jansson considers how Cox's ideas about secularisation were received in Sweden by analysing the reception in the media and academia, as well as the study material accompanying the book. Apart from outlining secularisation theory as a time-specific form of knowledge, the chapter highlights the adaptation of an internationally renowned work into a new national context. Further, it discusses the relationship between religion and knowledge, specifically the role of churches, and the entanglement of knowledge and moral convictions.

Kari H. Nordberg's chapter studies bodies of sexual knowledge in school sex education. Using the teachers' manual as an arena of knowledge, it draws attention to the knowledge system of the Scandinavian state school and to curriculum texts as source material. Norwegian sex education had been influenced by biological and Christian knowledge since its introduction in the 1930s. With the 1960s, psychological and statistical knowledge on sexuality influenced the public discourse on sex education. These four bodies of knowledge, although frequently conflicting and contradictory, assembled and co-existed in the teachers' manual representing state-approved knowledge and values. Was it possible to harmonise sexual knowledge highlighting the importance of liberation and individual choice within a system of knowledge - the state school - governed by the "Christian object clause" and aimed at shaping youths' sexuality in a moral, responsible manner?

Hampus Östh Gustafsson charts the circulation of the idea regarding a crisis of the humanities that experienced new intensity in the 1970s, in particular in Sweden, where these fields of knowledge were regarded as exceptionally marginalised. Historical narratives of this marginalisation were contrasted to 
Sweden's leading position as a welfare state but also used for a new kind of critical societal mobilisation of knowledge in the humanities through specific institutional practices and publishing strategies, for which transnational comparisons and joint Scandinavian platforms were decisive. This caused the discourse of crisis to expand beyond national limitations. The problems identified for the humanities may thus be seen as characteristic of Scandinavian social democratic welfare states on a more general level, as they prioritised ideals of rational planning and social engineering. By demonstrating how the mobilisation of the humanities went hand in hand with a critique of these welfare societies, the author generates new perspectives on the societal role of knowledge in postwar Scandinavia.

Ragni Svensson's chapter focuses on the movement of independent Scandinavian socialist book cafes through an analysis of three different venues: two in Sweden and one in Denmark. The book cafe phenomenon emerged in France and West Germany during the late 1960s to then spread across Western Europe. As a result of conditions that were both political and cultural, and dependent on processes in the national book markets, book cafes were soon to gain a foothold within the emerging Scandinavian New Left movement. Here, book cafes are viewed as nodal points within the print culture of the leftist movement of the 1970s. They formed important links in a large network made up by producers and distributors of print and other media across the region. In this chapter, the circulation of knowledge within the Scandinavian New Left movement, as well as its links to society at large, is examined through a book and media history perspective.

\section{Epilogue}

At the end of the book, the Finnish intellectual historian Johan Strang situates the chapters in a larger Nordic context. He starts by making some general outsider reflections on the emerging field of the history of knowledge, before discussing what the book contributes with regard to the role of Scandinavia in the global circulation of knowledge, the relations between the Scandinavian countries, and knowledge in the welfare state and the particular period in focus in this book. In his epilogue, Strang asks if there was a Scandinavian corporatist model of knowledge in the 1960s and 1970s and what has happened to this particular "knowledge regime" since then.

\section{Notes}

1 Robert E. Lane, "The Decline of Politics and Ideology in a Knowledgeable Society", American Sociological Review 31, no. 5 (1966); Daniel Bell, "The Measurement of Knowledge and Technology", in Indicators of Social Change: Concepts and Measurements, eds. Eleanor Bernert Sheldon and Wilbert E. Moore (New York: Russell Sage Foundation, 1968); Peter Drucker, The Age of Discontinuity: Guidelines to Our Changing Society (New York: Harper \& Row, 1969); Daniel Bell, The Coming of Post-Industrial Society: A Venture in Social Forecasting (New York: Basic Books, 1973). Prior to this, already in the 1950s 
and early 1960s, other scholars, such as Robert M. Solow and Fritz Machlup, had made important contributions to the discussion on the role of knowledge in the growing postwar economy.

2 Marian Adolf and Nico Stehr, Knowledge (Abingdon, Oxon: Routledge, 2014); Jenny Andersson, The Library and the Workshop: Social Democracy and Capitalism in the Knowledge Age (Stanford: Stanford University Press, 2010); Arne Jarrick, Det finns inga häxor: En bok om kunskap (Stockholm: Weyler, 2017), 43-69.

3 In this book, Scandinavia comprises Denmark, Norway, and Sweden. Some authorities argue for the inclusion of Finland, Iceland, and the Faroe Islands in the concept; however, for this larger region, we use the term "the Nordic countries". See "Scandinavia”, Encyclopedia Britannica, accessed 15 September 2019, www.britannica.com/place/ Scandinavia.

4 Harald Gustafsson, "A Nordic Perspective - Why? Why Not?" in Internationalisation in the History of Northern Europe: Report of the Nordsaga '99 Conference, University of Tromsø, 17-21 nov 1999, eds. Richard Holt, Hilde Lange, and Ulrike Spring (Tromsø: University of Tromsø, 2000); Harald Gustafsson, "Om Nordens historia”, Scandia 67, no. 2 (2001); Erik Bodensten, Kajsa Brilkman, David Larsson Heidenblad, and Hanne Sanders, "Inledning”, in Nordens historiker: En vänbok till Harald Gustafsson, eds. Erik Bodensten, Kajsa Brilkman, David Larsson Heidenblad, and Hanne Sanders (Lund: Mediatryck, 2018), 9-13. See also Pertti Haapala, Marja Jalava, and Simon Larsson, eds., Making Nordic Historiography: Connections, Tensions and Methodology, 1850-1970 (New York: Berghahn Books, 2017).

5 For a historiographical overview of the field, see Johan Östling, David Larsson Heidenblad, Erling Sandmo, Anna Nilsson Hammar, and Kari H. Nordberg, "The History of Knowledge and the Circulation of Knowledge: An Introduction", in Circulation of Knowledge: Explorations in the History of Knowledge, eds. J. Östling, E. Sandmo, D. Larsson Heidenblad, A. Nilsson Hammar, and K. H. Nordberg (Lund: Nordic Academic Press, 2018); Suzanne Marchand, "How Much Knowledge Is Worth Knowing? An American Intellectual Historian's Thoughts on the Geschichte des Wissens", Berichte zur Wissenschaftsgeschichte 42, no. 2-3 (2019); Marian Füssel, "Wissensgeschichten der Frühen Neuzeit: Begriffe-Themen-Probleme", in Wissensgeschichte, ed. M. Füssel (Stuttgart: Franz Steiner Verlag, 2019); Johan Östling, "Circulation and Public Arenas of Knowledge: Developing New Directions in the History of Knowledge", History and Theory (forthcoming). Publications that played a key role in shaping the field in the 2010s include Peter Burke, A Social History of Knowledge: From Gutenberg to Diderot (Cambridge: Polity Press, 2000); Philipp Sarasin, "Was ist Wissensgeschichte?" Internationales Archiv für Sozialgeschichte der deutschen Literatur (IASL) 36, no. 1 (2011); Peter Burke, A Social History of Knowledge: From the Encyclopédie to Wikipedia (Cambridge: Polity Press, 2012); Peter Burke, What Is the History of Knowledge? (Cambridge: Polity Press, 2016); Simone Lässig, "The History of Knowledge and the Expansion of the Historical Research Agenda", Bulletin of the German Historical Institute 59 (2016); Lorraine Daston, "The History of Science and the History of Knowledge", KNOW: A Journal on the Formation of Knowledge 1, no. 1 (2017); Martin Mulsow and Lorraine Daston, "History of Knowledge", in Debating New Approaches to History, eds. M. Tamm and P. Burke (London: Bloomsbury Academic, 2019).

6 Östling, "Circulation and Public Arenas of Knowledge".

7 Johan Östling and David Larsson Heidenblad, "Fulfilling the Promise of the History of Knowledge: Key Approaches for the 2020s", Journal for the History of Knowledge (forthcoming).

8 Sarasin, "Was ist Wissensgeschichte?" 165.

9 Lässig,"The History of Knowledge and the Expansion", 58.

10 Johan Östling and David Larsson Heidenblad, "Cirkulation - ett kunskapshistoriskt nyckelbegrepp", Historisk tidskrift 137, no. 2 (2017); Johan Östling and David Larsson Heidenblad, "From Cultural History to the History of Knowledge", History of Knowledge (8 June 2017), accessed 1 September 2019, https://historyofknowledge.net/2017/06/08/ from-cultural-history-to-the-history-of-knowledge/; Östling and Larsson Heidenblad, "Fulfilling the Promise of the History of Knowledge". 
11 Östling and Larsson Heidenblad, "Cirkulation"; Östling et al., "The History of Knowledge". For a more detailed discussion, including additional bibliographical references, see these publications.

12 Kapil Raj, Relocating Modern Science: Circulation and the Construction of Knowledge in South Asia and Europe, 1650-1900 (Basingstoke: Palgrave Macmillan, 2007), 225; James A. Secord's own presentation of his ongoing research, accessed 1 September 2019, www. mpiwg-berlin.mpg.de/en/node/13708.

13 For perspectives on current variants of intellectual history, see Samuel Moyn and Andrew Sartori, eds., Global Intellectual History (New York: Columbia University Press, 2013); Darrin M. McMahon and Samuel Moyn, eds., Rethinking Modern European Intellectual History (Oxford: Oxford University Press, 2014); Richard Whatmore, What Is Intellectual History? (Cambridge: Polity Press, 2016).

14 Mary Hilson, The Nordic Model: Scandinavia Since 1945 (London: Reaktion, 2008), 11; Harald Gustafsson, Nordens historia: En europeisk region under 1200 år (Lund: Studentlitteratur, 2017), 308. However, see also, Lars Hovbakke Sørensen, Slagsbrødre eller broderfolk: Nordens historie gennem 1300 år (Copenhagen: Aschehoug, 2004); Niels Kayser Nielsen, Bonde, stat og hjem: Nordisk demokrati og nationalism - fra pietismen til 2. verdenskrig (Aarhus: Aarhus Universitetsforlag, 2009); Harm G. Schröter, Geschichte Skandinaviens (Munich: C.H. Beck, 2015).

15 For conceptual and historiographical accounts, see Nils Edling, ed., The Changing Meanings of the Welfare State: Histories of a Key Concept in the Nordic Countries (New York: Berghahn, 2019).

16 Niels Finn Christiansen, eds., The Nordic Model of Welfare: A Historical Reappraisal (Copenhagen: Museum Tusculanum Press, 2006); Francis Sejersted, The Age of Social Democracy: Norway and Sweden in the Twentieth Century (Princeton: Princeton University Press, 2011). See also Kazimierz Musiał, Roots of the Scandinavian Model: Images of Progress in the Era of Modernisation (Nomos: Baden-Baden, 2002); Eric S. Einhorn and John Logue, Modern Welfare States: Scandinavian Politics and Policy in the Global Age (Westport, CT: Praeger, 2003); Astri Andresen et al., Barnen och välfärdspolitiken: Nordiska barndomar 1900-2000 (Stockholm: Dialogos, 2011); Grete Brochmann and Anniken Hagelund, Immigration Policy and the Scandinavian Welfare State 1945-2010 (Basingstoke: Palgrave Macmillan, 2012); Peter Scharff Smith and Thomas Ugelvik, eds., Scandinavian Penal History, Culture and Prison Practice: Embraced by the Welfare State? (Basingstoke: Palgrave Macmillan, 2017).

17 Thorsten B. Olesen, ed., The Cold War-And the Nordic Countries: Historiography at Crossroads (Odense: University Press of Southern Denmark, 2004); Tony Insall and Patrick Salmon, eds., The Nordic Countries: From War to Cold War, 1944-1951 (London: Routledge, 2011); Henric Bastiansen and Rolf Werenskjold, eds., The Nordic Media and the Cold War (Gothenburg: Nordicom, 2015); Valur Ingimundarson and Rósa Magnúsdóttir, eds., Nordic Cold War Cultures: Ideological Promotion, Public Reception, and East-West Interactions (Helsinki: Aleksanteri Institute, 2015).

18 Henrik Stenius, Mirja Österberg, and Johan Östling, eds., Nordic Narratives of the Second World War: National Historiographies Revisited (Lund: Nordic Academic Press, 2011); John Gilmour and Jill Stephenson, eds., Hitler's Scandinavian Legacy: The Consequences of the German Invasion for the Scandinavian Countries, Then and Now (London: Bloomsbury Academic, 2013).

19 See, for example, Jussi Kurunmäki and Johan Strang, eds., Rhetorics of Northern Democracy (Helsinki: Helsinki Literature Society, 2010); Ida Blom, Medicine, Morality, and Political Culture: Legislation on Venereal Disease in Five Northern European Countries, c. 1870c. 1995 (Lund: Nordic Academic Press, 2012); Ulrika Dahl, Marianne Liljeström, and Ulla Manns, The Geopolitics of Nordic and Russian Gender Research 1975-2005 (Huddinge: Södertörn University, 2016); Ainur Elmgren and Norbert Götz, eds., The Political Culture of Nordic Self-Understanding: Power Investigation (London: Routledge, 2016); Johan Strang, ed., Nordic Cooperation: A European Region in Transition (New York: Routledge, 2016); Eva Blomberg, Yulia Gradskova, Ylva Waldemarsson, and Alina Žvinklienè, eds., Gender Equality on a Grand Tour: Politics and Institutions - The Nordic Council, Sweden, Lithuania 
and Russia (Leiden: Brill, 2017); Synnøve Bendixsen, Mary Bente Bringslid, and Halvard Vike, eds., Egalitarianism in Scandinavia Historical and Contemporary Perspectives (Cham: Springer International Publishing, 2018); Mia Liinason, ed., Equality Struggles: Women's Movements, Neoliberal Markets and State Political Agendas in Scandinavia (Abingdon: Routledge, 2018); Hanne Hagtvedt Vik, Steven LB Jensen, Linde Lindkvist, and Johan Strang, eds., "Histories of Human Rights in the Nordic Countries", Nordic Journal of Human Rights 36, no. 3 (2018).

20 Åsa Lundqvist and Klaus Petersen, eds., In Experts We Trust: Knowledge, Politics and Bureaucracy in Nordic Welfare States (Odense: University Press of Southern Denmark, 2010).

21 Hilson, The Nordic Model; Sejersted, The Age of Social Democracy; Gustafsson, Nordens historia.

22 Thomas Ekman Jørgensen, Transformation and Crises: The Left and the Nation in Denmark and Sweden, 1956-1980 (New York: Berghahn Books, 2008), 336. See also Kim Salomon, Rebeller i takt med tiden: FNL-rörelsen och 60-talets politiska ritualer (Stockholm: Rabén Prisma, 1996); Kjell Östberg, 1968 - när allting var $i$ rörelse: Sextiotalsradikaliseringen och de sociala rörelserna (Stockholm: Prisma, 2002); Thomas Ekman Jørgensen, "The Scandinavian 1968 in a European Perspective", Scandinavian Journal of History 33, no. 4 (2008); Tor Egil Førland, “"1968' in Norway: Piecemeal, Peaceful and Postmodern”, Scandinavian Journal of History 33, no. 4 (2008); Anette Warring, "Around 1968: Danish Historiograhpy", Scandinavian Journal of History 33, no. 4 (2008); Martin Wiklund, Historia som domstol: Historisk värdering och retorisk argumentation krig “68” (Nora: Nya Doxa, 2012).

23 Ann-Cathrine Jungar, "Populist Radical Right Parties in the Nordic Region: A New and Distinct Party Family?" Scandinavian Political Studies 37, no. 3 (2014); Bengt Lindroth, Väljarnas hämnd: Populism och nationalism i Norden (Stockholm: Carlsson, 2016); AnnCathrine Jungar, "Continuity and Convergence: Populism in Scandinavia”, in The Routledge Handbook of Scandinavian Politics, eds. Peter Nedergaard and Anders Wivel (London: Routledge, 2017).

24 The Swedish Social Democrats were pioneers in this respect. See Jenny Andersson, Between Growth and Security: Swedish Social Democracy From a Strong Society to a Third Way (Manchester: Manchester University Press, 2006), 105-127.

25 Liv Kari B. Tønnessen, Norsk utdanningshistorie: En innføring med fokus på grunnskolens utvikling (Oslo: Universitetsforlaget, 1995); Rune Slagstad, Ove Korsgaard, and Lars Løvlie, Dannelsens forvandlinger (Oslo: Pax, 2003); Gunnar Richardson, Svensk utbildningshistoria: Skola och samhälle förr och nu (Lund: Studentlitteratur, 2004); Esbjörn Larsson and Johannes Westberg, eds., Utbildningshistoria: En introduktion (Lund: Studentlitteratur, 2019); Anne Katrine Gjerløff, Anette Faye Jacobsen, Ellen Nørgaard, and Christian Ydesen, Da skolen blev sin egen: 1920-1970 (Aarhus: Aarhus Universitetsforlag, 2014); Ning de Coninck-Smith, Lisa Rosén Rasmussen, and Iben Vyff, Da skolen blev alles: Tiden efter 1970 (Aarhus: Aarhus Universitetsforlag, 2015).

26 Mette Buchardt, Pirjo Markkola, and Heli Valtonen, "Introduction: Education and the Making of the Nordic Welfare States", in Education, State and Citizenship, eds. Mette Buchardt, Pirjo Markkola, and Heli Valtonen (Helsinki: Nordic Centre of Excellence NordWel, 2013); Orsi Husz and Nikolas Glover, "Between Human Capital and Human Worth: Popular Valuations of Knowledge in 20th-Century Sweden", Scandinavian Journal of History 44, no. 4 (2019).

27 Walter Rüegg, ed., A History of the University in Europe: Universities Since 1945 (Cambridge: Cambridge University Press, 2011).

28 Fredrik W. Thue and Kim G. Helsvig, Universitetet $i$ Oslo 1945-1975: Den store transformasjonen (Oslo: Unipub, 2011); Carl-Gustaf Andrén, Visioner, vägval och verkligheter: Svenska universitet och högskolor i utveckling efter 1940 (Lund: Nordic Academic Press, 2013); Else Hansen, Professorer, studenter og polit.er: Om velfordsstatens universitetspolitik 1950-1975 (Copenhagen: Museum Tusculanum, 2017); Thomas Brandt et al., Avhengig av forskning: De norske forskningsrådenes historie (Bergen: Fagbokforlaget, 2019).

29 Klaus Bruhn Jensen and Ib Bondebjerg, eds., Dansk mediehistorie: 3: 1960-1995 (Copenhagen: Samleren, 1997); Lars-Åke Engblom, Karl Erik Gustafsson, and Per Rydén, Den 
svenska pressens historia: 4: Bland andra massmedier (efter 1945) (Stockholm: Ekerlid, 2002); Stig Hadenius, Kampen om monopolet: Sveriges radio och TV under 1900-talet (Stockholm: Prisma, 1998); Henrik Grue Bastiansen and Hans Fredrik Dahl, Norsk mediehistorie (Oslo: Universitetsforlaget, 2008); Jostein Gripsrud, ed., Allmenningen: Historien om norsk offentlighet (Oslo: Universitetsforlaget, 2017).

30 Michael Hagner, Zur Sache des Buches (Göttingen: Wallstein, 2015).

31 Gripsrud, Allmenningen; Ann Steiner, "The Modern Swedish Book Business, 18002000", in Oxford Research Encyclopedia of Literature, accessed 15 September 2019, http://literature.oxfordre.com/view/10.1093/acrefore/9780190201098.001.0001/ acrefore-9780190201098-e-270.

32 Östling and Larsson Heidenblad, "Cirkulation”, 279-284.

33 Johan Östling, "En kunskapsarena och dess aktörer: Under strecket och kunskapscirkulation i 1960-talets offentlighet", Historisk tidskrift 140, no. 1 (2020); Östling,"Circulation and Public Arenas of Knowledge".

34 Ibid.

35 See, for instance, Hampus Östh Gustafsson, "The Discursive Marginalisation of the Humanities: Debates on the Humanist Problem in the Early 1960s Swedish Welfare State", History of Humanities 3, no. 2 (2018).

36 Thomas Robertson, The Malthusian Moment: Global Population Growth and the Birth of American Environmentalism (New Brunswick: Rutgers University Press, 2012); Jacob Darwin Hamblin, Arming Mother Nature: The Birth of Catastrophic Environmentalism (Oxford: Oxford University Press, 2013); Rens van Munster and Casper Sylvest, eds., The Politics of Globality Since 1945: Assembling the Planet (London: Routledge, 2018); Perrin Selcer, The Postwar Origins of the Global Environment: How the United Nations Built Spaceship Earth (New York: Columbia University Press, 2018); Paul Warde, Sverker Sörlin, and Libby Robin, The Environment: A History of the Idea (Baltimore: Johns Hopkins University Press, 2018).

37 Andrew Jamison, Ron Eyerman, Jacqueline Kramer, and Jeppe Læssøe, The Making of the New Environmental Consciousness: A Comparative Study of the Environmental Movements in Sweden, Denmark and the Netherlands (Edinburgh: Edinburgh University Press, 1990); Bredo Berntsen, Grønne Linjer: Natur- og miljøvernets historie $i$ Norge (Oslo: Grøndahl Dreyer, 1994); Søren Hein Rasmussen, Sare alliancer: Politiske bevagelser i efterkrigstidens Danmark (Odense: Odense Universitetsforlag, 1997); Peder Anker, "Den store økologiske vekkelsen som har hjemsøkt vårt land", in Universitetet i Oslo: Bok 7, Samtidshistoriske perspektiver, ed. John Peter Collett (Oslo: Unipub, 2011); David Larsson Heidenblad, "Ett ekologiskt genombrott? Rolf Edbergs bok och det globala krismedvetandet i Skandinavien 1966", Historisk tidsskrift (NO) 95, no. 2 (2016); Anna Kaijser and David Larsson Heidenblad,"Young Activists in Muddy Boots: Fältbiologerna and the Ecological Turn, 1959-1974”, Scandinavian Journal of History 43, no. 3 (2018); Arne Kaijer and Jan-Henrik Meyer, “'The World's Worst Located Nuclear Power Plant': Danish and Swedish CrossBorder Perspectives on the Barsebäck Nuclear Power Plant”, Journal for the History of Environment and Society 3 (2018).

38 Jan Eckel, Geist der Zeit: Deutsche Geisteswissenschaften seit 1870 (Göttingen: Vandenhoeck \& Ruprecht, 2008); Rens Bod, A New History of the Humanities: The Search for Principles and Patterns From Antiquity to the Present (Oxford: Oxford University Press, 2013); Peter Mandler, “The Humanities in British Universities Since 1945”, The American Historical Review 120, no. 4 (2015).

39 Jesper Eckhardt Larsen, "ikke af brod alene .. ." Argumenter for humaniora og universitet $i$ Norge, Danmark, Tyskland og USA 1945-2005 (Copenhagen: Danmarks Pædagogiske Universitetsforlag, 2007); Kim G. Helsvig, Pax forlag 1964-2014: En bedrift (Oslo: Pax, 2014); Alexander Ekelund, Kampen om vetenskapen: Politisk och vetenskaplig formering under den svenska vänsterradikaliseringens era (Gothenburg: Daidalos, 2017); Ragni Svensson, Cavefors: Förlagsprofil och mediala mytbilder i det svenska litteratursamhället 1959-1982 (Lund: Ellerströms, 2018). 